\title{
The Effect of Holistic Comprehensive Health Service Approach Through Family Functions on Optimizing the Nutrition Status of Junior High School Students
}

\author{
Febri Endra Budi Setyawan' ${ }^{1}$ C.E. Widiadi ${ }^{2}$ \\ ${ }^{1}$ Lecturer in The Faculty of Medicine, University of Muhammadiyah Malang \\ ${ }^{2}$ Medical Faculty Students, University of Muhammadiyah Malang \\ Email : febri@umm.ac.id
}

Received : Feb 10 ${ }^{\text {th }}$ 2020. Revised : May 25 ${ }^{\text {th }}$ 2020. Published : Jun 27th2020

DOI: https://doi.org/10.22219/sm.Vol16.SMUMM1.12687

\begin{abstract}
Background : Nutritional status problems have many causes, including genetic, body metabolic conditions, behavior, environment, culture, and socioeconomic factors. One environmental factor that receives relatively limited attention is that children are exposed to undue stress, especially family stress. One of the factors influencing a child's nutritional status is his family. Family functions that run well can optimize the process of growth and development of children which can be described by the nutritional status. Optimization of nutritional status in children can not only be done from a clinical approach alone but needs holistic comprehensive management.
\end{abstract}

Objective : The purpose of the study was to analyze the effect of a holistic comprehensive health service approach through family functions on optimizing the nutritional status of junior high school students.

Method: This study was an observational analytic study with a cross sectional approach with the subjects of Malang City's "Z" Junior High School students. Implementation in May- August 2019. The research subjects were 265 people with multistage random sampling. Data collection by interview. The analysis is displayed in the form of frequency distribution and correlation using the Spearman test and logistic regression

Results and Discussion : Family function is quite influential on nutritional status $(\mathrm{r}=0.445)$. In logistic regression, the equation $\mathrm{Y}=8.563-0.582 \mathrm{X} 1-0.992 \mathrm{X} 2-0.606 \mathrm{X} 3$ is obtained. The most influential family function is partnership of $99.2 \%$. Partnership describes communication, mutual sharing, mutual complementarity between family members in all problems faced by family members, as well as the level of deliberation in making decisions and or resolving a problem that is being faced with other family members. Comprehensive holistic health service approach is sufficient effect on nutritional status $(\mathrm{r}=$ $0.463)$.

Conclusion : The holistic comprehensive health service approach gives sufficient influence on the nutritional status of students in Malang City's "Z" Junior High School.

Key words: Nutritional status, APGAR Family, Holistic Comprehensive 


\section{INTRODUCTION}

Basic Health Research (2018) shows that nationally there has been a decline in the prevalence of underweight and very thin nutrition, from 12.1\% in 2013 to 10.2\% in 2018, but the prevalence in 20 provinces is still above the national prevalence value and there are 2 provinces whose prevalence has increased (Gorontalo and NTB). In the nutritional status of fat, the prevalence in 2018 decreased compared to 2013, from $11.8 \%$ to $8 \%$, however there are still 13 provinces with prevalence above the national prevalence (Ministry of Health Republic of Indonesia, 2019).

Nutritional status problems have many causes, including genetic, body metabolic conditions, behavior, environment, culture, and socioeconomic factors. One environmental factor that receives relatively limited attention is that children get undue exposure to stress, especially family stress (Rooney, Mathiason and Schauberger, 2011). One of the factors influencing a child's nutritional status is his family. Discussing the influence of family, family is defined as a social construction in which a group of people is bound by heredity, marriage, adoption or choice. Aspects of family function that are closely related to the risk of nutritional status problems in children include weak communication between family members, poor control of behavior from parents, frequent conflicts in the family and low value of the family hierarchy. The family is a group that has an important role in preventing and improving the child's growth and development process (Soetjiningsih, 2013; Sutikno, 2011). Family functions that run well can optimize the process of growth and development of children which can be described by their nutritional status (Almatsier 2010; Soetjiningsih, 2013).

Optimization of nutritional status in children can not only be done from a clinical approach alone but needs holistic comprehensive management. Health is not only influenced by physical factors of the disease but also from the social and psychological dimensions of the patient (biopsychosocial model) as well as from his family and community. Attention to the social and psychological dimensions will make doctors more effective in solving physical health problems. (Borrell et al., 2004)

The purpose of this study was to analyze the effect of a comprehensive holistic health service approach through family functions on optimizing the nutritional status of junior high school students.

\section{METHOD}

\section{Research Design}

This research is an analytic observational research with cross sectional approach. The research was conducted at Malang City's "Z" Junior High School in May-August 2019. 


\section{Reseach population and sample}

The population and sample of this research are Malang City "Z" Junior High School students. Determination of the sample size using the Slovin formula with sampling techniques using multistage random sampling, which obtained a number of samples in as many as 265 people. The selected sample was students in grades VII, VIII, IX who were active in the 2019/2020 school year.

\section{Research Data Analysis}

In this study, data were obtained from interviews with a reference questionnaire conducted on Malang City "Z" Junior High School students. Data obtained from respondents' answers will be processed, tabulated and presented in tabular form. Then the correlation analysis of the variables examined was done using the Spearman test and then the logistic regression test was performed.

\section{RESULTS}

Malang City "Z" Junior High School was a junior high school that develops the School's Health Clinic program by providing health services with a holistic comprehensive approach. The results of the study are shown in the following table:

Table 1. Distribution of Gender Characteristics.

\begin{tabular}{ccc}
\hline Sex & Frequency & Percentage \\
\hline Male & 120 & 45,3 \\
Female & 145 & 54,7 \\
\hline Total & 265 & 100 \\
\hline
\end{tabular}

There is no significant difference in the gender of students in Malang City's "Z" Junior High School, with the female gender being slightly more dominant $(54,7 \%)$.

Table 2 Distribution of Family Function Indicators

\begin{tabular}{ccc}
\hline Indicator & Mean & Standard Deviation \\
\hline Adaptation & 2,37 & 0,75 \\
Partnership & 2,58 & 0,66 \\
Growth & 2,38 & 0,73 \\
Affection & 2,53 & 0,70 \\
Resolve & 2,22 & 0,76 \\
\hline
\end{tabular}

The family function indicator has an average value of $>2.00$ which shows that all indicators can be concluded reasonably well. 
4 Setyawan F. E. B., C. E. Widiadi/ SM Vol.16 No.1 June 2020 Page 1-13

Table 3. Distribution of Family Function Categorization

\begin{tabular}{crrrrrc}
\hline $\begin{array}{c}\text { Indicator } \\
\text { Family Function }\end{array}$ & \multicolumn{2}{c}{ Less } & \multicolumn{2}{c}{ Enough } & \multicolumn{3}{c}{ Good } \\
\hline & $\mathbf{n}$ & $\mathbf{0}$ & $\mathbf{n}$ & $\mathbf{\%}$ & $\mathbf{n}$ & $\mathbf{\%}$ \\
\hline Adaptation & 43 & 16.2 & 81 & 30.6 & 141 & 53.2 \\
Partnership & 25 & 9.4 & 62 & 23.4 & 178 & 67.2 \\
Growth & 40 & 15.1 & 85 & 32.1 & 140 & 52.8 \\
Affection & 31 & 11.7 & 63 & 23.8 & 171 & 64.5 \\
Resolve & 54 & 20.4 & 97 & 36.6 & 114 & 43.0 \\
\hline
\end{tabular}

Overall dominant indicators are in the good category $(43 \%-67 \%)$, with the partnership indicator having the highest value in the good category $(67,2 \%)$.

Table 4. Nutrition Status Distribution

\begin{tabular}{ccc}
\hline Nutritional status & Frequency & Percentage \\
\hline Abnormal & 177 & 66.8 \\
Normal & 88 & 33.2 \\
\hline Total & 265 & 100.0 \\
\hline
\end{tabular}

Table 5. Distribution of a Holistic Comprehensive Health Service Approach

\begin{tabular}{crr}
\hline Holistic Comprehensive Approach & Frequency & Percentage \\
\hline Never & 86 & 32.5 \\
Sometimes & 98 & 37.0 \\
Always & 81 & 30.6 \\
\hline Total & 265 & 100.0 \\
\hline
\end{tabular}

Table 6. Cross Tabulation of Gender with Nutrition Status.

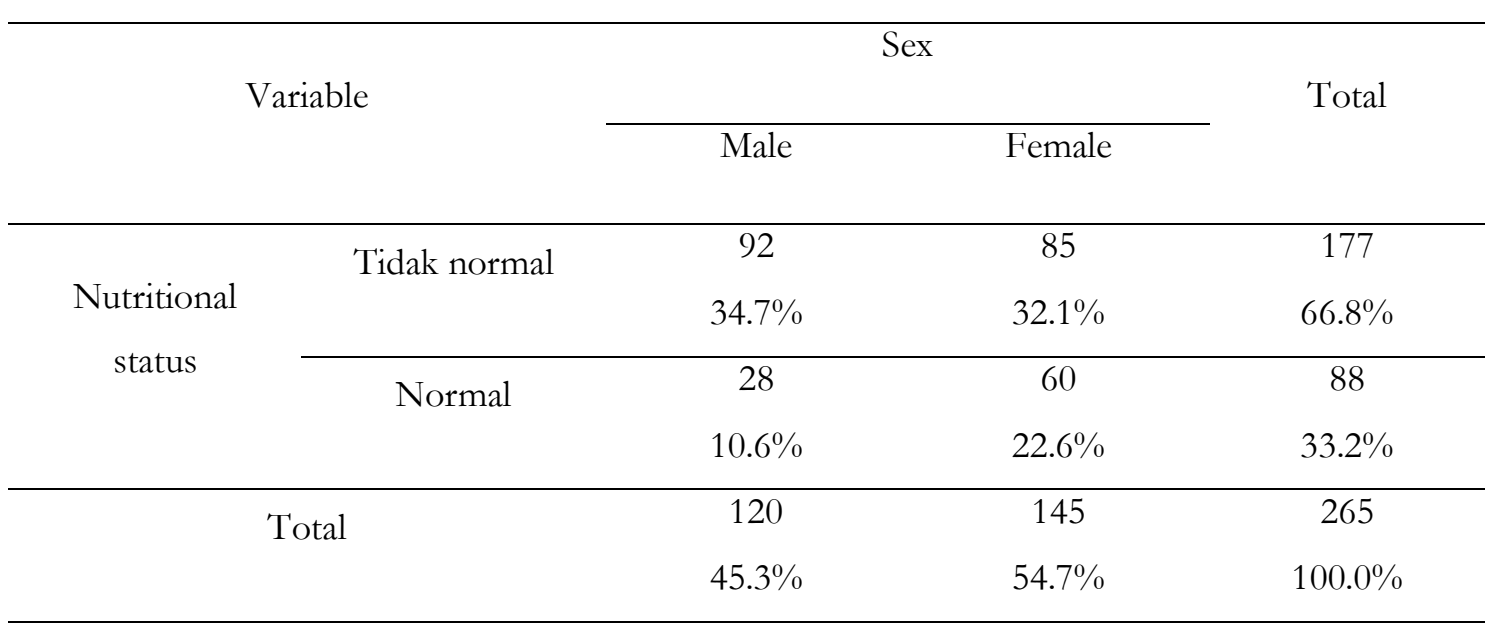

Table 7. Cross Tabulation of Family Functions with Nutrition Status Variable Family Functions

\begin{tabular}{cccccc}
\cline { 3 - 4 } & & Less & Enough & Good & \\
\hline Nutritional & Tidak normal & 17 & 81 & 79 & 177
\end{tabular}




\begin{tabular}{cccccc}
\hline status & & $6.4 \%$ & $30.6 \%$ & $29.8 \%$ & $66.8 \%$ \\
\cline { 2 - 5 } & & 0 & 8 & 80 & 88 \\
& & $0.0 \%$ & $3.0 \%$ & $30.2 \%$ & $33.2 \%$ \\
\hline \multirow{2}{*}{ Normal } & 17 & 89 & 159 & 265 \\
& & $6.4 \%$ & $33.6 \%$ & $60.0 \%$ & $100.0 \%$ \\
\hline
\end{tabular}

Most respondents' nutritional status $(66.8 \%)$ was in the abnormal category, that is, body weight outside the normal graph. There was no significant difference in Malang City "Z" Junior High School students in obtaining a comprehensive holistic health service approach in the School's Health Clinic. In an abnormal nutritional status, (outside the normal graph) there were no significant differences between the sexes of men and women, but in Normal nutritional status (in the normal chart) shows that female gender is more dominant. abnormal nutritional 4 status, family function is dominant in the sufficient category $(30.6 \%)$, whereas in normal nutritional status, family function is very dominant in the good category $(30,2 \%)$.

\section{ANALYSIS}

The analysis was carried out in a bivariate and multivariate way to determine the effect of family function and holistic comprehensive health service approaches on nutritional status.

Table 8 Correlation of Family Function and Nutrition Status

\begin{tabular}{cccc}
\hline Correlation & Sig. & $\begin{array}{c}\text { Strength of } \\
\text { Correlation }\end{array}$ & $\begin{array}{c}\text { Correlation } \\
\text { Interpretation }\end{array}$ \\
\hline $\begin{array}{c}\text { Family function with } \\
\text { nutritional statusz }\end{array}$ & 0,000 & 0,445 & Sedang \\
\hline
\end{tabular}

Table 9. Correlation of Holistic Comprehensive Services with Nutrition Status

\begin{tabular}{cccc}
\hline Correlation & Sig. & Strength of Correlation & $\begin{array}{c}\text { Correlation } \\
\text { Interpretation }\end{array}$ \\
\hline $\begin{array}{c}\text { Pelayanan Holistik } \\
\text { Komprehensif dengan } \\
\text { Status Gizi }\end{array}$ & 0,000 & 0,463 & Sedang \\
\hline
\end{tabular}

Table 10. Logistic Regression of Family Functions

\begin{tabular}{ccc}
\hline Indicator & Sig. & Value \\
\hline Adaptation (X1) & 0,040 & 0,582 \\
Partnership (X2) & 0,010 & 0,992 \\
Growth (X3) & 0,030 & 0,606 \\
\hline
\end{tabular}




\begin{tabular}{ccc}
\hline Affection $(\mathrm{X} 4)$ & 0,149 & 0,442 \\
Resolve (X5) & 0,058 & 0,428 \\
Konstanta & 0,000 & -8.563 \\
\hline
\end{tabular}

Nutritional status is influenced by family function with a correlation value of 0.445 which is interpreted to be moderately correlated. Table 9 shows that nutritional status is also influenced by health services, in this case School's Health Clinic services that carry out a comprehensive holistic approach with a correlation value of 0.463 , which is interpreted to be moderately correlated.

\section{DISCUSSION}

The function of the family is enough to influence the nutritional status of Malang "Z" Public Middle School students. The results of this study are not in accordance with Hanifah's research (2017) about the relationship of family function with the nutritional status of children under five in Bandung Regency which states that aspects of family function with APGAR Family do not have a significant relationship on nutritional status. Khasanah research (2012) shows a consistent result, which states that good family parenting has a close relationship with the nutritional status of children because parents will provide protection, education, and will care for their children lovingly, therefore socialization is needed. of the importance of the role of the family for the growth and development of children, in addition it was also said that the level of parental education supports parents in getting various kinds of knowledge about nutritional information needed by children. Gumawang Research (2016) about the relationship of family function with the nutritional status of children in elementary school students in Boyolali, concluded that a significant relationship was found between family function and the nutritional status of children.

The main function of the family is adaptation which covers the assistance of family members, in this case, parents accustom their children to consume foods that contain various kinds of nutritional needs needed by children. Partnership which includes solving family problems, if the child experiences obstacles or problems in consuming food, then the parent helps the child in dealing with problems in his diet for example by replacing the food the child prefers but the food still contains nutrients needed by children. Growth which includes the growth and development of individual families. In providing nutrition, parents can also observe the child's development and growth based on the various food intake received by the child. Affection which includes the emotional interaction of each family member. Parents in providing food intake to their children there will be an emotional bond between parents and children, namely a sense of parental care for children and the last is togetherness (resolve) which includes time with family. Parents share time with their children by eating together, for example: breakfast or dinner, while parents eat together with their children, parents can pay attention and give advice about good foods consumed by children. (Sutikno, 2011; Soetjiningsih, 2013). 
In handling the nutritional status of children, the family has a very important role 5 because in the family environment it is a place for children to maximize their growth and development, and fulfill their nutrition. Families that have good family functions and have good emotional ties can support growth and development. (Almatsier, 2010; Soetjiningsih, 2013).

APGAR Family was introduced by Gabriel Smilkstein in 1978 to assess someone's satisfaction with social support from the family. This is illustrated by the 5-item family support which includes adaptation, partnership, growth, affection and resolution and a focus statement on interactive emotional, communicative, and social relationships between the respondent and his family (William Gardner et al, 2001). The Family Adaptability and Cohesion Evaluation Scale (FACES) is an instrument for assessing family function. FACES uses the circumflex model introduced by Olson to assess marital and family functions, is one of the most widespread approaches using highly controversial family function models. This model emphasizes optimal family function referring to the balance between two dimensions: "Cohesion" and "Adaptability" (Olson, 1999).

Adaptation describes the ability of each family member to adapt to other family members, as well as satisfaction in receiving help, support and advice from other family members. This can be influenced by the mass media, because teenagers have a great interest in new things so that stereotypes are created from models displayed in the mass media, where these models have thin and slender bodies, which make a person more attractive and loved, raises teenage perception about body image like the model they idolized. Therefore many teenagers who try to follow the image as shown by the mass media and ignore their health (Fatimatuzzahro, 2016).

Vonderen and Kinnally (2012) suggest that the social environment, peers and parents are supporting factors that greatly influence adolescent perceptions in determining their thinking patterns. Perceptions about positive body image are greatly influenced by positive environmental and family factors (Fatimatuzzahro, 2016). For a child, the family is first and foremost a place for growth and development. The family is the most effective place in shaping the character and habits of life of children (Subianto, 2013).

Children tend to take actions as exemplified by their parents when caring for them (Harmaini, 2013). Children's habits are formed from habits adopted by their families, such as exercise habits and consuming fruits and vegetables. Exercise can stimulate the development of muscles so that it affects optimal growth. Adolescent nutritional status will be better if accompanied by regular exercise and a balanced nutritional diet (Kurniasih, 2010). This is supported by research conducted by Serly, et al (2015) regarding the relationship of body image, energy intake and physical activity with the nutritional status of 2014 Faculty of Medicine students of the University of Riau stating that there is a significant relationship between nutritional status and physical activity stated that as many as $64,4 \%$ of research respondents were normal weight with light physical activity. Siagian, et al (2017) research on the relationship of vegetable and fruit consumption with obesity in elementary school children IV in Pentecostal Elementary School 
Magelang 2017 shows that vegetable consumption influences the incidence of obesity. Partnership describes communication, mutual sharing, mutual filling among family members in all problems faced by family members, as well as the level of consultation in making a decision and or resolving a problem that is being faced with other family members.

Growth describes the family's support for new things done by each family member, including satisfaction of each family member of the freedom given by the family in maturing the growth and/or maturity of each family member. A child will grow and develop in accordance with its genetic potential and intake of nutrients consumed in the form of food (Pahlevi, 2012). Stunted growth and development is a problem that is often found in the community, so it is very important if all components involved in child growth and development also monitor. As early as possible monitoring the growth and development of children includes monitoring of physical, psychological, and social aspects that must be done regularly and continuously by parents. Therefore, knowledge about early detection of children's growth and development needs to be possessed by parents. The ultimate goal of early monitoring of child developmental disorders is of course our hope in the realization of a generation of hope for a better and better quality nation (Chamidah, 2009).

Affection describes the relationship of affection and emotional interaction that takes place in the family. The presence of parents in the 6 child's growth and development process is very important, so if the child loses the role and function of his mother in the growth and development process loses the right to be fostered, guided, given affection, attention and so on, then the child will experience maternal deprivation, if the second role the parent is not functioning the child experiences parental deprivation. The family is the first place for children to learn emotions, such as how to recognize emotions, feel emotions, and express emotions. Every parent realizes that a child's primary needs are attention and affection. Quality attention and care from parents to children impact on children's growth and development (Harmaini, 2013). However Harmaini's research (2013) shows the results that parents still consider that the most important thing in a family is the fulfillment of economic needs, and other needs such as emotional, psychological and togetherness are not a concern.

Resolve describes the satisfaction of family members for togetherness and time spent with other family members, including the distribution of wealth, time, and space between family members. Based on Harmaini's research (2013) shows that as many as $65.5 \%$ of parents are not near their children while they are not working. The results of this study indicate that the time spent by parents is more often outside the home than at home. This indicates that the togetherness and attention of parents to children will be weak. The existence of parents is very important and a big influence on the child's growth and development process. Parents who are always around their children will be easier to give attention to their children compared to parents who are far from their children. Warm and open family closeness in the form of children's meetings and togetherness with parents can stimulate individuals to express themselves openly and safely. The negative impact of the lack of togetherness of parents and children is that children can become dependent on other 
than their parents such as technology instead of parents, this dependency will increase the time to do other activities.

One of the factors that influences the nutritional status is gender. Sari's (2012) research on factors related to adolescent nutritional status states that gender has a relationship with nutritional status in adolescents. This study is in accordance with Restiani's study (2012) about the relationship of body image, energy intake and macro nutrients and physical activity with nutritional status, which states that normal nutritional status is highest in women (56.8\%). However, the results of this study are not in line with Restiani's research which states that the nutritional status is higher in male sex $(56.2 \%)$, where in this study for abnormal nutritional status, ie outside the normal chart there is no significant difference between types male and female genitals.

Ruslie and Darmadi (2012) states that the factors that influence adolescent nutritional status, where male respondents have a tendency of overweight nutritional status that is equal to $(29.63 \%)$ while female respondents tend to have underweight and normal nutritional status that is equal to $(85,56 \%)$. This situation is due to nutrient deficiencies more common in girls than in boys. Adolescent girls are at risk of experiencing nutritional problems namely micronutrient deficiencies (Dhamayanti, 2013). Based on the results of the above explanation, it can be concluded that adolescent girls are prone to experiencing malnutrition status and adolescent boys tend to experience over nutritional status.

Nutritional status can be influenced by the level of family's social economy, knowledge, education, lifestyle, diet, energy consumption level, and protein consumption level (Pahlavi, 2012; Myrnawati and Anita, 2016). Adequate family income will support the child's growth and development process, because parents can provide for their child's basic needs (Soetjiningsih, 2013). So that when linked in the discussion in this study, parents are able to meet the food needs of children while outside the home by providing pocket money or food supplies. Indarti's research (2016) shows that the family's economic status has a significant relationship to the nutritional status of children under five in Ajung Subdistrict, Jember Regency in 2016. However, other research shows that there is no significant relationship between the economic level of the family and the nutritional status of children in Air Tawar Barat Village, Padang City (Burhani, et al. 2016).

Nutritional status can be influenced by the level of family's social economy, knowledge, education, lifestyle, diet, energy consumption level, and protein consumption level (Pahlavi, 2012; Myrnawati and Anita, 2016). Adequate family income will support the child's growth and development process, because parents can provide for their child's basic needs (Soetjiningsih, 2013). So that when linked in the discussion in this study, parents are able to meet the food needs of children 7 while outside the home by providing pocket money or food supplies. Indarti's research (2016) shows that the family's economic status has a significant relationship to the nutritional status of children under five in Ajung Subdistrict, Jember Regency in 2016. However, other research shows that there is no significant relationship between the economic level of the 
family and the nutritional status of children in Air Tawar Barat Village, Padang City (Burhani, et al. 2016).

The family has a very important role in handling nutritional status problems in children because the family environment is a place for children to maximize the process of growth and development, as well as the fulfillment of their nutrition. Families who have good family functions and emotional ties can optimize growth and development in their children (Almatsier 2010; Soetjiningsih, 2013).

The School's Health Clinic has a strategic role in helping to monitor the nutritional status of school children or the nutritional status of students. The School's Health Clinic Trias are: 1) Health education; 2) Health services and 3) Fostering a healthy school environment must be carried out properly (Apriani and Gazali, 2018). The model of health education and health services should follow the healthy paradigm dimension, meaning that it is more concerned with promotive and preventive efforts. Both of these efforts are one of the principles of a comprehensive holistic health service approach.

Health education and health services in the School's Health Clinic "Z" Junior High School at Malang City have enough impact on the nutritional status of Malang "Z" Junior High School students. When looking at the distribution of the nutritional status of dominant students that is not normal, then the holistic comprehensive health service approach has not been well implemented by the School's Health Clinic team. This is shown in table 5.5 where there is no difference in the implementation of a holistic comprehensive health service approach in the School's Health Clinic. Therefore, it is better for the UKS team to also involve medical doctors who understand the concept of a comprehensive holistic service approach.

WHO defines health as a complete area of physical, mental and social which is not solely a matter of disease and weakness. Health is more than just the absence of disease, health is an appreciation of physical, mental and social balance (WHO, 2014). The School's Health Clinic team, especially medical staff must know that health is not only influenced by physical factors but also from the patient's social and psychological dimensions (biopsychosocial models) as well as from their families and communities. Attention to the social and psychological dimensions will make doctors more effective in solving physical health problems. (Borrell et al, 2004). See humans as biopsychosocio-cultural creatures in their ecosystem. Humans are biological creatures which are organ systems, formed from tissues and cells that are functionally complex (Alimul, 2006). Holistic is seeing all organism's life as interaction. Interference with one part will disrupt the system as a whole. In other words, a disturbance in one part will have an impact on the whole (Salbiah, 2006).

\section{CONCLUSION}

The holistic comprehensive health service approach gives sufficient influence on the nutritional status of students "Z" Junior High School at Malang City. The function of the family "Z" Junior High School at Malang City, students was in good categorization. The nutritional status 
of students "Z" Junior High School at Malang City was mostly in an abnormal nutritional status (outside the normal graph) and female gender dominated the normal nutritional status. Holistic comprehensive health service approach there is no significant difference in its implementation in the School's Health Clinic "Z" Junior High School at Malang City. Indicators of adaptation, partnership and growth in family function influence the nutritional status of students " $Z$ " Junior High School at Malang City.

\section{REFERENCES}

Almatsier, S. 2010. Prinsip Dasar Imu Giri, Jakarta: Penerbit PT Gramedia Pustaka Utama. Hal: 312, 144-149.

Alimul, A.A. 2006. Pengantar Kebutuban Dasar Manusia. Jakarta: Salemba Medika.

Borrell, F., A. Suchman, R. Epstein. 2004. The Biopsychosocial Model 25 Years Later: Principles. Practice. and Scientific Inquiry. An Nals of Family Medicine. Vol.2(6):576-582.

Burhani, P.A., F. Oenzil, G. Revilla. 2016. Hubungan Tingkat Pengetahuan Ibu dan Tingkat Ekonomi Keluarga Nelayan dengan Status Gizi Balita di Kelurahan Air Tawar 8

Barat Kota Padang, Jurnal Kesehatan Andalas, Volume.5(3): 515-521.

Chamidah, A. N. 2009. Deteksi Dini Gangguan Pertumbuhan dan Perkembangan Anak, Jurnal Pendidikan Khusus JPK Universitas Negeri Yogyakarta. Volume. 5(2): 83-93.

Dogar, I Ahmad. 2007. Biopsychosocial Model. Annals of Punjab Medical College Vol.1(1):11-13

Depkes RI, 1994, Pedoman Praktis Memantau Status Giri Orang Dewasa. Jakarta.

Dhamayanti, M. 2013. Overview Adolescent Healt Problems and Servuces. Diperoleh dari: http://idai.or.id/artikel/seputar-kesehatan-anak/over view-adolescent-health-problemsand-services [diunduh pada tanggal 9 Agustus 2019].

Fatimatuzzahro, U. 2016, Hubungan Body Image dengan Status Giri Siswo Kelas XI di SMKN 4 Yogyakarta. Diperoleh dari: http://digilib.unisayogya.ac.id/2483/1/NASPUB\%20Miee.pdf [diunduh pada tanggal 11 Oktober 2019].

Friedman, M.M. 2010. Buku Ajar Keperawatan Keluarga: Riset, Teori, dan Praktek, Edisi 5, Jakarta: EGC. Hal: 3-24.

Gumawang Z.A. Hubungan Fungsi Keluarga dengan Status Giæi Anak pada Murid di SDN 5 Kediri. 2016;1-4.

Harmaini. 2013. Keberadaan Orang Tua Bersama Anak. Jurnal Psikologi UIN Sultan Syarif Kasim Riau. Volume.9(2): 80-93.

Indarti, Y. 2016, Hubungan Status Ekonomi Keluarga dengan Status Gizi Balita di Kecamatan Ajung Kabupaten Jember Tahun 2016. Fenomena, Volume. 15(1): 149-162.

Khasanah U., 2012. Hubungan Pola Asub dan Kharakteristik Keluarga dengan Status Giripada Anak Usia Sekolah di SD Negeri Kelurahan Tugu Kota Depok. Universitas Indonesia. Jakarta. Thesis. 
Kurniasih, D. 2010. Sehat dan Bugar Berkat Giz̨i Seimbang. Jakarta: Gramedia. Hal. 34-39.

Lestari, E.G., S. Humaedi, M Budiarti S. 2017. Peran Keluarga Dalam Menanggulangi Kenakalan Remaja, Jurnal Penelitian dan PKM. Volume. 4(2):153-159.

Myrnawati dan Anita, 2016, Pengaruh Pengetahuan Gizi, Status Sosial Ekonomi, Gaya Hidup dan Pola Makan terhadap Status Gizi (Studi Kausal di Pos PAUD Kota Semarang Tahun 2015). Jurnal Pendidikan Usia Dini, Volume 10(2): 213-232.

Olson, D.H. 1999. Empirical Approaches to Family Assessment. Journal of Family Thyerapy. Volume 14 (2): $1-10$

Pahlevi, A.E. 2012. Determinan Status Gizi pada Siswa Sekolah Dasar. Jurnal Kesehatan Masyarakat. Vol. 7(2): 122-126.

Prasetyawat, A.E. 2010, Kedokteran Keluarga. Jakarta: Rineka Cipta. Hal: 32-36.

Pujiati, A., S. Rahmalia. 2015. Hubungan antara Perilaku Makan dengan Status Gizi pada Remaja Putri, The Journal of The Minerals, Metals \& Materials Society (TMS). Volume 2(2): 1345-1352. Republik Indonesia. 2004. Undang-Undang Nomor 40 Tabun 2004 Tentang Sistem Jaminan Sosial Nasional. Lembaran Negara Republik Indonesia Tahun 2004 Nomor 150. Jakarta.

Restiani N. 2012. Hubungan Citra Tubuh, Asupan Energi dan Zat Gizi Makro serta Aktivitas Fisik dengan Status Gizi Lebih pada Siswa SMP Muhammadiyah 31 Jakarta Timur Tahun 2012. Diperoleh dari: http://lib.ui.ac.id/file?file=digital/20320278-S-Novita\%20Restiani.pdf [diunduh pada tanggal 22 September 2019].

Riset Kesehatan Dasar, 2018, Badan Penelitian dan Pengembangan Kesehatan Kementrian Kesehatan RI, Jakarta. Diperoleh dari: http://www.depkes.go.id/resources/download/general/Hasil\%20Riskesdas\%202013.pdf [diunduh pada tanggal 22 September 2019].

Rooney, B.L., M.A Mathiason., C.W Schauberger. 2011. Predictors of Obesity in Childhood, Adolescence, and Adulthood in A Birth Cohort. Matern Child Health Journal. Volume.15(8): 1166-75.

Ruslie, R.H, Darmadi. 2012. Analisis Regresi Logistik untuk Faktor-Faktor yang Mempengaruhi Status Gizi Remaja. Majalah Kedokteran Andalas. Volume.36(1): 62-71.

Sari, R. I. 2012, Faktor-faktor yang Berhubungan Dengan Status Gizi Remaja Usia 12-15 Tahun di Indonesia Tahun 2007. diperoleh dari: http://lib.ui.ac.id/file?file=digital/20294684-SRatna\%20Indra\%20Sari.pdf [diunduh pada tanggal 18 Oktober 2019].

Serly, V., A. Sofian., Y. Ernalia. 2015. Hubungan Body Image, Asupan Energi dan Aktivitas Fisik Dengan Status Giri Pada Mahasiswa Fakultas Kedokteran Universitas Rian Angkatan 2014, Diperoleh dari: https://jom.unri.ac.id/index.php/JOMFDOK/article/view/4860 [diunduh pada tanggal 11 Oktober 2019].

Siagian, D.M., A. Mursyid., T. N. S. Hartini. 2017. Hubungan Konsumsi Sayur dan Buah dengan Obesitas pada Anak SD Kelas IV-VI DI SD Pantekosta Magelang Tabun 2017, diperoleh dari: 
http://eprints.poltekkesjogja.ac.id/238/1/29DARUWATI\%20M\%20S.pdf [Diakses pada: 25 Oktober 2019].

Soetjiningsih, I.G.N Gde Ranuh. 2013. Tumbuh Kembang Anak. Edisi 2..Jakarta: EGC. Hal: 61-72, 224-233, 256-268.

Story M. 2002. Individual and Environmental Influences on Adolescent Eating Behavior. Diperoleh dari: https://www.ncbi.nlm.nih.gov/pubmed/11902388 [Diunduh pada tanggal 29 Desember 2019].

Subianto, J. 2013. Peran Keluarga, Sekolah, dan Masyarakat dalam Pembentukan Karakter. Edukasia: Jurnal Penelitian Pendidikan Islam. Volume.8(2): 331-354

Supariasa, I. D. N. 2002, Penilaian Status Gizi. Jakarta: ECG. Hal: 19-27, 30-99.

Sutikno, Ekawati. 2011. Hubungan antara Fungsi Keluarga dan Kualitas Hidup Lansia. Jurnal Kedokteran Indonesia, Volume.2(1): 73-78.

UNICEF, 2015. Causes and Most Vulnerable to Undernutrition. http://www.unicef.org/ nutrition/training/2.5/4.html.

Vonderen, K.E.V dan W. Kinnally. 2012. Media Effects On Body Image: Examining Media Exposure in the Brooder Context of Internal and Other Social Factors, American Communication Journal. Volume. 14 Issue 2: 41-57.

WHO. 2014. Basic Documents 48th ed. WHO Press. World Health Organization. 20 Avenue Appia. 1211 Geneva 27. Switzerland. p-1.

Wirghana Indra, Edi Muin, Witri Windrawati, dkk., 2013, Buku Pengantar Kader BKR tentang Delapan Fungsi Keluarga, BKKBN, Direktorat Bina Kesehatan Remaja, Jakarta. Diperoleh dari: http://bkk.bantulkab.go.id/filestorage/berkas/2015/07/buku_8_fungsi_keluara [Diunduh pada tanggal 29 Desember 2019 